\title{
THE POTENTIAL OF VIRTUE ETHICS IN ETHICAL EDUCATION IN SLOVAKIA
}

\author{
Barbora Bad'urová \\ Department of Ethical and Civic Education, \\ Faculty of Education, Matej Bel University, \\ Slovakia \\ barbora.badurova@umb.sk
}

Received: 31 May 2018

\begin{abstract}
Virtue ethics is an approach to normative ethics that emphasizes the great character traits of moral agents. As many authors have pointed out, this approach also has great potential in contemporary ethical education. The following text will focus on the possibility practically utilising virtue ethics in ethical education in Slovakia. One of the most influential figures in the development of this topic in Slovakia is Ladislav Lencz, who also created key texts for teachers of ethical education. His concept is based primarily on a pedagogical and psychological basis, inspired by Spanish psychologist R.R. Olivar's concept of prosociality. However, some of L. Lencz's texts also display elements of virtue ethics. This article will point out the possibilities of implementing virtue ethics in ethical education.
\end{abstract}

Key words: ethical education, virtue ethics, Slovakia

\section{Introduction}

Walker and Thoma (2017), among others, have observed that virtue-based ethical or character education is in ascendance both in theory and in practice. This might be due to the several advantages that the virtue-based approach has in comparison to other normative ethical theories. It is often believed that this approach is better able to grasp solutions for moral problems. Moreover, it is often suggested in education that the virtue ethics approach offers a plausible combination of the cognitive, affective, and behavioural dimensions (the "head, heart, and hands") of teaching and learning. 
The following article is divided into three main sections. The first one deals with the nature of virtue ethics in general. The nature and the discussion over challenges of virtue-based ethical education is sketched in the second section. The last, third section, focuses on the elements and possibilities of further application of virtue based approach into Ethical education in Slovakia.

\section{Virtue ethics}

Virtues may be characterized as certain excellent character traits. As a branch of normative ethics, virtue ethics stresses the virtues and moral character of the agent. This approach therefore differs slightly from consequentialism, which focuses mostly on the consequences of actions and deontology, which mostly discusses duties and following certain rules.

To illustrate these differences, we will use a simplified example in which we are to imagine that we must preside over a case in which someone has stolen money. From the point of view of deontology, we would say that he/she did a bad thing, because he/she violated a rule that prohibits stealing. Consequentialism would recommend looking at the consequences of stealing, and if the prevalent consequences are negative (or worse than in the other alternative), it would deem the act wrong. According to virtue ethics, we would concentrate on the character of the agent and would likely say that the agent did not act honestly.

However, this should not give the impression that virtue ethics cannot cooperate with the other two approaches to normative ethics. All three approaches can make room for virtues, consequences, rules or duties. Therefore, virtue ethicists are not the only ones who attend to virtues, while consequentialists rely only on consequences and deontologists focus only on rules. As several authors (e.g. Husthouse, Pettigove, 2016; Kawall, 2009) have already pointed out, it seems that any plausible normative ethical theory will have something to say about consequences, duties, and virtues. However, it is the centrality of virtue within the theory that distinguishes virtue ethics from other normative ethical theories. Concepts of virtues are thus fundamental to virtue ethics, whereas proponents of deontological ethics will explain them as character traits of people who fulfil their duties, and authors committed 
to consequentialism will define them as certain traits that lead to good consequences.

In this regard, it is interesting that the authors of Current Controversies in Virtue Theory (2015) point out that some virtue theories are focused more on consequences and others on motives (see Alfano et al., 2015). This may seem confusing, as it has been stated above that virtue ethics is a third approach to normative ethics that emphasises virtues instead of consequences and duties. How, then, may one interpret this? It is important to distinguish between virtue theory and virtue ethics; the former tries to enrich the other normative ethical theories with the aspect of virtues, while the latter is oriented towards virtue ethics as an alternative to other theories of normative ethics.

Although it has been mentioned that virtues are particular excellent character traits of moral agents, one may wonder what a virtuous person is like. As R. Hurtshouse and G. Pettigove (2016) put it:

"To possess a virtue is to be a certain sort of person with a certain complex mindset. A significant aspect of this mindset is the wholehearted acceptance of a distinctive range of considerations as reasons for action." (Hurtshouse, Pettigove, 2016)

This is related to the idea that a truly virtuous person does something for the right reasons while also having the appropriate feelings. Actions that only outwardly resemble virtuous actions do not count. So, if we wish to call someone honest in accordance with virtue ethics, it is not enough that the person tells the truth regardless of the reason he or she has for doing so. If the person does so merely out of fear that he or she may be caught, or to impress someone, this does not count as a truly virtuous action according to virtue ethics. The agent must perceive the true reason for the action and understand that it would be dishonest for he or she to act otherwise. R. Hursthouse and G. Pettigove (2016) clarify as follows:

"An honest person cannot be identified simply as one who, for example, tells the truth because it is the truth, for one can have the virtue of honesty without being tactless or indiscreet. The honest person recognises 'That would be a lie' as a strong (though perhaps not overriding) reason for not making certain statements in certain circumstances, and gives due, but not overriding, weight to 'That would be the truth' as a reason for making them." (Hurtshouse, Pettigove, 2016) 
As mentioned above, the fully virtuous agent has the appropriate emotions and feelings as well. However, it is not always unproblematic to have emotions that are in accord with our rational acknowledgement of out reasons for action. The perfectly virtuous agent is able to do what is right without any inner struggle against contrary desires. Based on the ideas of Aristotlean virtue, ethicists point to continence, or strength of will, because the imperfectly virtuous person has to control temptations and desires that tempt him or her to do otherwise.

This makes it apparent that contemporary virtue ethics also often follows the ideas of ancient thinker Aristotle, who is considered one of the real founders of ethics as a practical philosophy. Despite the fact that this author wrote his key text, the Nicomachean Ethics (1999), more than two thousand years ago, his approach still finds proponents. The author describes the nature of moral and intellectual virtues and analyzes the purpose of our lives, concluding that welfare - eudaimonia - and being truly virtuous leads to true happiness. The key idea of his normative theory is the idea of the golden mean. The virtuous agent is able to consider a situation and reasons for action to find the mean between extremes - appropriate actions are virtuous because extreme actions are vices. Vices do not reach or overreach the appropriate extent. To get a more complete picture of virtue ethics, it is worth mentioning that likely the most influential $20^{\text {th }}$ century and current authors, such as E. Anscombe, B. Williams, R. Hursthouse, A. MacIntyre, were also inspired by Aristotle's texts. This is why Aristotle and Aristotelians will be mentioned in the following text.

To sum up, virtue ethics focuses on the character of moral agent. This approach is therefore distinct from other classical approaches to normative ethics. It seems advantageous in the sense that it better captures moral problems and is more flexible in offering solutions. However, learning how to be virtuous may be more complicated than in other approaches. This is due to the idea that virtues are not based on basic moral rules that a person can easily learn and then unproblematically apply to specific situations in order to act virtuously. It requires certain experience, sensitivity, developed practical reasoning, and the ability to perceive the complexity of a situation, which often takes a very long time to develop. (Athanassoulis, 2018). The following part will deal with the implementation of virtue ethics in ethical education and some of its problems. 


\section{Virtue ethics in ethical education and its challenges}

The idea of ethical (or character) education based on virtues was popular from the time of Plato and Aristotle until the Enlightenment under the influence of David Hume. A resurgence of Aristotelianism and virtue ethics is also apparent in the $21^{\text {st }}$ century, as many academics emphasise the idea that education should create suitable conditions for children to flourish (Walker, Thoma, 2017). As Sanderse (2012) points out, this approach to ethical education can prevent the rise of ethical relativism and diminish the threat of repeating monstrosities such as those of World War II. What is interesting in virtue ethics is the fact that, since ancient Greece, it has often been connected to social and political philosophy, and thus ethical and socio-political problems are often viewed as interrelated.

Some authors link virtue-based approaches to ethical education with socialisation methods. This is due to the idea that children acquire knowledge and understanding of virtues through a gradual understanding of social norms and traditions (Durkheim, 1961). An issue raised by critics is that of who should decide what socialisation and teaching content should be (Walker, Thoma, 2017).

Character or ethical education based on virtue ethics has been criticized for being too conservative, highly individualistic, and often religious (Walker, Thoma, 2017). Other problems that have been mentioned by its critics are the problem of indoctrination, the lack of development of critical thinking, the issue of balance between emotions and rationality, lacking guidelines for appropriate conduct, etc. Some of the major issues will be dealt with below.

Let us begin with the issue of critical thinking. As Nel Noddings $(1998,15)$ has pointed out:

“Educators may take a special interest in Aristotle's moral thought because it established a model of moral education still widely popular. Aristotle recommended that children should be trained on morally appropriate modes of conduct." (Noddings, 1998, 15)

However, this may be interpreted to mean that virtue ethics in education is possible only as strict moral training or a kind of mechanical drill. Some critics therefore worry that virtue ethics (especially based 
on Aristotle) is too heavily focused on habituation, and that the development of critical thinking (if any) is merely secondary.

This problem is also related to the idea that virtue ethics education is necessarily tied to communitarianism, as some of these elements are apparent in Aristotle's texts. Noddings points out the given communitarian nature of virtue ethics, when she explains that

"Aristotle believed that the community should inculcate values in children and immerse them in supervised activities designed to develop relevant virtues. He was not concerned about teaching them to reason about moral matters. Indeed, he believed that young people were not ready for such reasoning until sometime in their twenties. By then, he argued, they would be good (virtuous) people and could be trusted to analyze moral issues. Before that time, they should learn to respond ethically out of the habits of good character. In turn, this good character would furnish the ground upon which future reasoning might be safely conducted." (Noddings, 1998, 15)

As Noddings (1998) writes, this understanding of ethical education has the order - teaching that allows for certain form of critical thinking (after becoming an adult), and is likely often adopted by contemporary religious education because of its conservative nature. The idea of character education in the sense of so-called 'moral training' is thus criticized by those who are concerned about imposing values through the process of indoctrination, as they fear it will leave little room for critical thinking.

However, the refutation of Aristotle's moral education (or virtue ethics education in general) on this grounds is somehwat complicated, as is shown in Kristján Kristjánsson's Aristotle, Emotions, and Education (2010). This author mentions e.g. R. S. Peters' approach, which suggests children should be lead to critical thinking through habits and traditions on the basis of Aristotles writings - children "can and must enter the place of Reason through the courtyard of Habit and Tradition" (Kristjánsson, 2010, 32). This can thus be understood as a gradual process that does not totally exclude critical thinking, while simultaneously relying strongly on traditions that may be perceived as quite conservative.

Kristjánsson $(2010,34)$ points out that Burnyeat interprets Aristotle such that

"... moral learners would hardly be on the way to the desirable state of understanding 'why' of morality if they were not in the process of forming rea- 
sonable and reflective ideas about the nature of the virtues. So the practice of moral learning must involve some cognitive powers into which moral educators can gradually tap.” (Kristjánsson, 2010, 34)

On the other hand, Sherman offers a more radical, innovative Aristotelian approach to virtue ethics that raises more hope for critical thinking. She writes that Aristotle's texts, although discussing habituation, require that the moral learner practice judgement and reason from the outset. However, she points out that this transition is somewhat mysterious. Kristjánsson presents her interesting interpretation of habituation:

"Through habituation, the child is not manipulated (for such manipulation would never lead to full virtue), but rather gradually brought to more critical discriminations with the guidance of an outside instructor." (Kristjánsson, 2010, 35)

I assume that certain elements of the development of critical thinking are necessary for any ethical education, even for young children, because critical thinking helps them grasp the complexity of moral reality and find the best possible solution. Moreover, it can be in line with virtue ethics as a part of the development of practical reason.

Another problem related to the aforementioned issue regarding critical thinking stems from the communitarian nature of education in general:

"When virtues are identified within a particular society, they may escape critical examination." (Noddings, 1998, 104)

This is due to the communitarian idea that education should follow the traditions and values of a particular society, which do not always have to be plausible as some societies may have traditional practices that e.g. oppose the idea of basic universal human rights, which may therefore make following them counterintuitive to most people. Moreover, another issue is that contemporary societies are often pluralistic instead of homogenous, and often also feature pluralistic value systems (Noddings, 1998, 105). Therefore, it may be difficult to say which values are typical of a given society, which are not, and which should be followed.

D. Carr (2005), as a contemporary proponent of ethical education based on virtue ethics, also outlines problems and dilemmas in contemporary ethical education with relation to the debate between communitarianism and liberalism. He - perhaps surprisingly - agrees to some 
extent with both of them in that education must involve exposure to thick values, as well as in that students or citizens should not be indoctrinated with any comprehensive theory of good. On the other hand, he assumes that both doctrines have resulted in errors regarding values, and that these have problematic implications for contemporary educational policy and its creation. According to Carr, liberalism falsely infers from peoples' right to their own opinions to radical agnosticism regarding rational basis of value judgements. Similarly, communitarianism falsely assumes that maximalist moral values are preserved in various cultural narratives (eg. in myths or imaginative fictions), and that their only function may be to promote social solidarity among those communities that share these different stories. Carr, however, claims that these narratives may be of benefit to anyone, not just to a particular local community (Carr, 2005).

Carr's approach is indeed interesting as he refutes the idea that virtue ethics (and education based on this ethical grounds) must be inevitably committed to communitarian doctrine; he thus attempts to find a plausible solution somewhere between these political doctrines, which seems to be the best approach. This influential contemporary proponent of virtue ethics in education claims that:

"To construe moral education as a matter of initiation into the attitudes and values of civilized sensibility- rather than as a matter of socialization into conventional codes of conduct (or even as emotionally disengaged cognitive reflection on such socialization) - is to appreciate that the evaluative capacities and qualities of affect presupposed to the cultivation of such sensibility are barely conceivable in the absence of those rich resources of normative enquiry and reflection provided by the great human artistic and literary traditions. Hence, although it would also be mistaken to hold that their value is entirely exhausted by their moral import, the central role of literature and the arts in any process of moral formation- properly conceived as an education of the heart as well as the head - would seem hard to deny." (Carr, 2005, 149-150)

This approach seems interesting as the author suggests the more complex development of the moral agent through ethical education rather than through simple mechanical socialisation, which does not leave much room for critical thinking and practical reasoning. This also seems more plausible for real life applications in which the moral agent must be sensitive to circumstances, and in which the mechanical application of certain rules might be counterintuitive. 
Moreover, the given interpretation of ethical education aims to find the right balance between emotions and reason. This approach:

“... holds out the best prospect for an account of moral association, character and education that does appropriate justice to the moral interplay of principle and affect, or of reason and emotion." (Carr, 2005, 140)

Carr (2005) argues the importance of both reason and emotions, claiming that we should not adopt the extreme prevalence of only one of them. He bases his argument for adopting virtue ethics in education on the apparent disadvantages of an extreme interpretation of the ethics of principle (based on the ideas of Kohlberg or Kant) and ethics of care (based on ideas of Gilligan), two approaches that were influential in the $20^{\text {th }}$ century. The former has difficulties explaining motivation, while the latter is too heavily oriented towards emotions and too little towards reason (Carr, 2005). As he puts it: "thoughts without passion are impotent, feeling without reason is blind" (Carr, 2005, 141).

The affective and cognitive side of the individual seem to be interrelated. However, it is possible to point out that some states like anger or fear seem to be more affective than cognitive. On the other hand, some evaluative attitudes that are more complex have more cognitive content than affective content (Carr, 2005). ${ }^{1}$ Carr interestingly argues that:

“... virtue ethics provides a rather more theoretically sophisticated view of the complexities of moral life than character education." (Carr, 2005, 140)

This is an interesting point since some authors understand virtueethics-based education as character education, or at least believe these concepts to be similar.

It may be interesting to note that there are several different terms that are often used interchangeably - 'moral education', 'character education', 'ethical education', 'ethics education' (or 'value education'). ${ }^{2}$ The term 'moral training' is also similar. Some authors do

\footnotetext{
${ }^{1}$ However, the proper understanding of emotions is a complex issue. Carr (2005) points out that, even if we were to have a satisfactory, exhausting philosophical account of feeling and emotion and their true nature, this account would not be able to tell us straightforwardly what we ought to feel (e.g. fear, pity, or love). It would be especially unable to specify this for any given set of circumstances. This problem is also central to any question about how we are to educate in the emotional sense.

${ }^{2}$ In this text I also often use this terms synonymously.
} 
distinguish between them, but their interpretations may differ. The distinction is often based on the relationship to indoctrination and freedom in education. For instance, moral training is often used to designate education that is quite similar to indoctrination in which there is no room for critical thinking (see e.g. Siipi, 2006). Similarly, some authors also interpret character education as the cultivation of character through methods of indoctrination. However, in Carr's text, it is related to ethics of principle, which is based on the ideas of Kohlberg and Kant.

Most authors also use the term 'character education' for education that is in line with virtue ethics based on critical thinking (e.g. Ferkany, Creed, 2014). Value education may also sometimes be interpreted as having the goal of influencing the value orientation of children in a given direction. The terms 'moral education', 'ethical education', and 'ethics education' are often more neutral in this regard.

However, the contemporary proponents of virtue ethics often propose education based on the development of practical reason, which is not as dogmatic as pure indoctrination. Carr (2005) points out the importance of practical reason and principled reflection. Similarly to most contemporary virtue ethicists, he perceives this ethical theory as more of an ethics of judgement as opposed to a deontically-principled ethics of duty or utility. This is due to the determination of the best solution as a means between extremes, which cannot be lamented solely through the mechanical application of a particular general rule. However, Carr (2005) simultaneously claims that it is still possible for virtue ethics to rely on absolute prescriptions or prohibitions in the narrow sense, e.g. the prohibition of murder, etc., as pointed out by Aristotle and similarly understood by many $20^{\text {th }}$ - and $21^{\text {st }}$-century virtue ethicists (e.g. Geach, 1977; Hursthouse, 1999). Nevertheless, when the imperatives conflict, the virtuous agent should have to choose the lesser of two evils, as Carr (2005) writes, e.g. "to lie in order to save lives" (Carr, 2005, 140). As Carr puts it, unlike utilitarians, who are committed to evaluating given actions as morally justifiable due to their consequences, the virtue ethicist would regard them as inherently wrong (Carr, 2005). ${ }^{3}$ This is an

${ }^{3}$ An interesting discussion exists also regarding reading of Aristotle's ethics in terms of generalism and particularism. There are authors who incline towards generalist reading like Reeve, Irwin, Kristjánsson. On the other hand there are also proponents of particularist reading of Aristotle like McDowell and Vasiliou (Kristjánsson, 2010). 
interesting conclusion, as I believe virtue ethics, although perhaps not offering the ideal solution in real world situations, does allow the virtuous person to remain blameless if the best possible decision still results in harm. However, I am unsure whether this could be interpreted as inherently wrong. I believe that virtue ethics would see this act as plausible and would not deem it wrong.

Again, to determine the right decision, it is important to train one's practical reasoning. Similarly, Matt Ferkany and David Creed (2014) are proponents of virtue-based ethical education, especially in the form they call 'intellectualist Aristotelian character education'. They argue against numerous objections to this kind of ethical education. They stress the importance of developing practical intelligence, which helps the agent decide in specific situations. This is due to the fact that they agree to some extent with the claim that right action is uncodifiable. I agree with this approach, as I believe that virtue ethics offers an approach that is, albeit uncodifiable, relies on the existence of plausible solutions - in other words, it does not say that anything goes.

Ethical education based on virtue ethics is gaining in popularity. This is likely due to the fact that it tries to find a middle ground between extremes in numerous ways. Its proponents claim that, if correctly interpreted and developed, it is especially able to offer a balance between critical thinking and habituation, communitarian and liberal thought, emotions and reason. One of the strongest elements is likely its potential for practical reasoning, which is able to help the moral agent resolve complex issues. However, this approach needs must be further developed in order to clarify how to implement all the aspects of virtue ethics into practical education.

\section{Elements of virtue ethics in current ethical education in Slovakia}

I will first describe the nature of ethical education in Slovakia, followed by an outline of the elements of virtue ethics taught in this subject and of possibilities to further utilise the topic.

Currently, ethical education is a compulsory elective subject in Slovakia that is considered an alternative for students who do not attend religious education. It has been taught in primary and secondary education in Slovakia since the fall of the socialist totalitarian regime 
in the 1990s. ${ }^{4}$ The key figures in the establishment of this subject in the country are authors such as Roberto Roche Olivar and Ladislav Lencz (see e.g. Lencz, Krížová, 2004; Lencz, 1993a; 1993b). Although he is a Spanish psychologist, emeritus professor and lecturer at the Universidad Autónoma de Barcelona, Olivar strongly influenced the Slovak concept of the subject. He has been developing his theory of prosociality education since the 1980s. The establishment of the subject was also influenced by the authors of the Character Development Project - E.A. Wynne, K. Ryan, T. Lickona, and the Child Development Programme - D. Solomon, D. Watson, V. Battistich. Olivar's ideas were modified to Slovak education by Ladislav Lencz, who developed special pedagogical elements of prosociality education. He and his colleagues wrote various useful handbooks for teachers of ethical education with numerous proposed exercises and activities.

Despite the fact that Ladislav Lencz wrote his books around 20 years ago, his texts are still influential and used by many teachers of ethical education. This stems from the fact that methodical materials on the subject are uncommon. ${ }^{5}$ This is likely also due to the fact that majority of new materials focuses solely on selected topics in ethical education.

Ethical education (along with its alternative, confessional religious education) in the Slovak curriculum falls within the educational area entitled 'Man and Values'. The current State Educational Programme for Higher Secondary Education (2015) explains that the main task of ethical education is to actively form the personality of students with their own identity and value orientation. Especially significantly, it teaches respect for people, nature, and life. One of the main goals of the subject is to promote prosociality, which represents the core of ethics between people. The subject is also intended to teach cooperation and help students create harmonious social relationships. The state curriculum claims that ethical education should not focus only on providing information on moral principles, but should particularly encourage the understanding and internalisation of moral standards and the adoption of behaviour that is consistent with them. Therefore, 'experiential

\footnotetext{
${ }^{4}$ Since 1993 it has been taught in the independent Slovak Republic.

${ }^{5}$ Due to the lack of suitable teaching materials in the project APVV-14-0176 we created handbooks for teachers oriented for instance on implementation of cross-curricular topics (e.g. environmental ethics and education) into Ethical education.
} 
learning' methods are especially desirable. The educational programme says that the cognitive knowledge of students serves only as a means to value reflection.

For example, the national curriculum for lower secondary education (State Educational Programme - Ethical Education for Lower Secondary Education, 2015) proposes the following topics: open communication; knowing and positively assessing others; ethical aspects of environmental protection; identifying and expressing emotions; cognitive and emotional empathy; positive role models in everyday life; positive role models in history and literature; sources of the ethical knowledge of mankind. For ethical education in secondary schools, the State Educational Programme proposes seven main topics that represent an educational standard: communication; the dignity of the human being; sexual ethics; good family relationships; philosophical generalisation of the ethical norms acquired so far; work ethic; ethics and the economy; healthy lifestyle. (State Educational Programme - Ethical Education for Grammar Schools, 2015)

In the article "Ethical education in Slovakia from the philosophical point of view" (2017), I point out that the ethical education unfortunately lacks elements of philosophical ethics, focusing rather on the pedagogical and psychological aspects of ethical education. Ladislav Lencz, who is still one of the most influential authors of methodical materials for ethical education in Slovakia, does not explicitly analyse problems of philosophical ethics in ethical education, instead implicitly outlining them. For instance, Lencz admits that the issue of standards and values as basic categories of ethical education should be developed in terms of philosophy and philosophical ethics (as well as philosophical anthropology) (Lencz, 1993a). Nevertheless, he does not offer any deeper analysis of the problem, dealing instead in pedagogical and psychological approaches.

Although the national curriculum (State Educational Programme for Grammar Schools, 2015) contains a theme entitled "Philosophical generalization of acquired ethical standards" (higher secondary education), its content is only partly philosophical as its objective is to know moral values, one's own ambitions and life goals, the role of conscience, the difference between legal and moral norms, current ethical problems, etc. Although they inform learners of the importance of critical thinking, both this topic in particular and the curriculum in general do not 
always suggest educational goals that are in accordance with this. For instance, it quite often emphasises the affective side of education.

On the other hand, it is important to mention that students can acquire some knowledge of philosophical ethics in a subject entitled "Civic Education", which is a compulsory subject; it does not focus solely on ethics, instead providing an introduction to several branches of the social sciences and humanities, such as political science, psychology, sociology, economics, and philosophy. This subject falls in the national curriculum within the area "Man and Society". 6

I assume that the ethical education course also creates space for philosophical normative ethics, e.g. on the basis of virtue ethics, Aristotle's texts, etc. Although most texts dedicated to Slovak Ethical Education do not mention this approach, one set of methodical materials written by Lencz and his team (Metodický materiál $k$ predmetu etická výchova 2 ; 1994) explicitly suggests utilising Aristotle's virtue ethics for educational purposes (Lencz et al., 1994, 18-20).

These authors suggest an activity focused on virtues that is suitable for students of lower and higher secondary education. They write about skills and virtues. They clarify skills such as being able to creatively solve demanding tasks easily or routinely. As an example, they mention a skilful driver who is able to drive relaxed and cautiously at the same time, and is also able to solve problematic situations without any issues (Lencz et al., 1994, 18).

They claim that the most important skills are those that contribute to our meaningful life, and that these can be understood as virtues. In this chapter, the authors also mention Aristotle as one of the most famous proponents of virtue ethics. They briefly characterize his understanding of virtues - that they are necessary to lead a happy life and are in accordance with our rational nature. They also highlight his idea of virtue as a means of negotiating extremes; to illustrate this, they also quote a short passage from his Nicomachean Ethics ${ }^{7}$ in which he discusses this theme (Lencz et al., 1994, 19). Later, they mention and briefly characterize Aristotle's four cardinal virtues (Lencz et al., 1994,

${ }^{6} \mathrm{An}$ interesting teaching material is for instance Občianska náuka pre stredné školy 2. čast' (2017) which offers also several philosophical exercises.

${ }^{7}$ They also recommend this literature for the activity focused on the topic origin and sources of ethics (Lencz et al., 1994, 39). 
19). They also briefly mention friendship as important idea in his ethics (Lencz et al., 1994, 20). Unfortunately, they do not discuss other Aristotelian virtues, and therefore this chapter can lead to the misunderstanding that Aristotle proposed only four virtues.

Lencz and his colleagues also created a task for students that is oriented towards a discussion on finding balance in our actions and finding the golden mean between extremes in our everyday life. They mention e.g. assertiveness as a golden mean between aggressiveness and passivity, or between an addiction to television and excluding it entirely. Students are also asked to think about their own actions in everyday life and reflect when they do not achieve the right balance (Lencz et al., 1994, 20). However, despite the positive fact that this activity popularises Aristotle's ideas, it may unfortunately lead to a misinterpretation of this great philosopher. Aristotle writes that the mean is not an arithmetic average, but rather that it must be adjusted to a given situation (Aristotle, 1999). In some situations, it may be appropriate to act in a way that is closer to one extreme and closer to the average in another. In addition to Aristotle's ideas, Lencz and his team also offer an approach to the virtues of German-American psychologist E. Erikson (Lencz et al.. 1994, 20-22), which forms another small chapter of the book. However, this virtue approach is focused primarily on developmental psychology and moral psychology instead of philosophical ethics.

Nevertheless, I believe that virtue ethics has potential for use in contemporary ethical education in Slovakia. It can even be implemented into most topics in the current State Educational Programme. For instance, in the higher secondary education topics "Communication or identifying and expressing emotions", the teacher may deal with the problem of appropriate emotions (as mentioned in Carr, 2005); similarly, the teacher may deal with economical virtues in the topic "Work ethic, ethics and economics". The topic "Ethical aspects of environmental protection" also has great potential for developing virtues and the idea of respect for nature as a virtue. The topics "Positive role models in everyday life" and "Positive role models in history and literature" also offer space for discussing virtues and observing the virtuous actions of role models. ${ }^{8}$

\footnotetext{
${ }^{8}$ For some suggestion to role models and cultivation of appropriate emotions see e.g. Kristjánsson, 2010.
} 
As mentioned above, I assume that certain elements of the development of critical thinking are very useful in any form of ethical education, even for young children. This is also in line with virtue ethics as a part of the development of practical reason. Therefore, I believe that ethical education in Slovakia should be more greatly enriched through this approach, as an understanding of ethical education as moral training that offers only ready-made solutions is not always sufficient for or appealing to students.

\section{Conclusion}

Ethical education based on virtue ethics has also found many proponents in the current century. The approach is appealing as it overcomes some of the disadvantages of its alternative, it seems to offer a balance between the rational and emotional development of the personality and between liberal and communitarian education, and it offers the attractive idea of practical reason. The problem is how to implement it in practice in schools. As Ferkany and Creed (2014) suggest, ethical education must not only be taught in schools, but also by parents, family members, friends, and society as well. It is possible to agree with their claim that, in order to become virtuous, one needs a good social environment. Thus, to successfully implement this approach, proper societal changes are often also required.

But which methods should teachers use for ethical education? As Walker and Thomas (2017) suggest, virtue based education can be based on methods such as role modelling, direct teaching, or service learning, which can be also implemented in several topics of the ethical education course. Ferkany and Creed (2014) suggest more experiential learning than theoretical learning (e.g. naming, describing, or discussing virtues). This practical learning may also support the idea that education should promote flourishing, not only on the individual level, but on the social (Ferkany, Creed, 2014; Carr, 2008) and environmental level as well. 


\section{Bibliography}

Alfano, Mark (ed.) (2015), Current Controversies in Virtue Theory, New York: Routledge. doi: https://doi.org/10.4324/9781315728001

Aristotle (2009), Nicomachean Ethics, Kitchener: Batoche Books.

Athanassoulis, Nafsika (2018), "Virtue ethics", in: Internet Encyclopedia of Philosophy. Available at: https://www.iep.utm.edu/virtue/\#H1[8 February 2018]

Bad’urová, Barbora (2017), "Ethical education in Slovakia from a philosophical point of view", Europa Forum Philosophie: Ethical Education, 66(1), pp. 104-114.

Bojnák, Štefan (2017), Občianska náuka pre stredné školy II. Čast', Bratislava: Orbis Pictus Istropolitana.

Carr, David (2005), "On the contribution of literature and the arts to the educational cultivation of moral virtue, feeling and emotion", Journal of Moral Education, 34(2), pp. 137-151. doi: https://doi.org/10.1080/03057240500127053

Carr, David (2008), "Character education as the cultivation of virtue", in. Nucci, Larry P.; Narvaez, Darcia (eds.), Handbook of Moral and Character Education, New York: Routledge, pp. 9999116.

Durkheim, Emile (1961), Moral Education, Glencole: The Free Press.

Ferkany, Matt; Creed, Benjamin (2014), "Intellectualist Aristotelian character education: An outline and assessment”, Educational Theory, 64(6), pp. 567-587. doi: https://doi.org/10.1111/edth.12084

Geach, Peter T. (1977), The Virtues, Cambridge: Cambridge University Press.

Hursthouse, Rosalind (1999), On Virtue Ethics, Oxford: Oxford University Press.

Hursthouse, Rosalind; Pettigrove, Glen (2016), "Virtue ethics", in: Stanford Encyclopedia of Philosophy. Available at:

https://plato.stanford.edu/entries/ethics-virtue/ [10 December 2017]

Kawall, Jason (2009), "In defence of the primacy of virtues", Journal of Ethics and Social Philosophy, 3(2), pp. 1-21. doi: https://doi.org/10.26556/jesp.v3i2.32

Kristjánsson, Kristján (2010), Aristotle, Emotions, and Education, Ashgate Publishing.

Lencz, Ladislav (1993a), Metódy etickej výchovy, Bratislava: Metodické centrum.

Lencz, Ladislav (1993b), Pedagogika etickej výchovy. Výchova k prosociálnosti, Bratislava: Metodické centrum.

Lencz, Ladislav et al. (1994), Metodicky material k predmetu eticka vychova 2, Bratislava: Metodické centrum.

Lencz, Ladislav; Krížová, Olga (2004), Metodický materiál k predmetu Etická výchova, Prešov: MPC. 
Siipi, Helena (2006), "Cultural dependency in the teaching of ethics: The case of Finland”, TRAMES, 10(60/55), 3, pp. 278-291.

Štátny vzdelávací program - Etická výchova - gymnázium so štvorročným a pätročným vzdělávacím programom (State Educational Program - Ethical education for grammar schools) (2015). Available at: http://www.statpedu. sk/files/articles/dokumenty/inovovany-statny-vzdelavaci-program/eticka vychova_g_4_5_r.pdf [9 March 2018]

Štátny vzdelávací program - Etická výchova - pre 2. Stupeň ZŠ (State Educational Program - Ethical education lower secondary education) (2015). Available at: http://www.statpedu.sk/sk/svp/inovovany-statny-vzdelavaci-program/inovovany-svp-2.stupen-zs/clovek-hodnoty/ [9 March 2018]

Noddings, Nel (1998), Philosophy of Education, Boulder: Westview Press.

Sanderse, Wouter (2012), Character Education: Neo-Aristotelian Approach to the Philosophy, Psychology and Education of Virtue, Delft: Eburon Academic Publishers.

Walker, David Ian; Thoma, Stephen J. (2017), "Moral and character education", in: Oxford Research Encyclopedia of Education, Oxford University Press. Available at: http://education.oxfordre.com/view/10.1093/acrefore/9780190264093.001.0001/acrefore-9780190264093-e-119 [12 January 2018] doi: https://doi.org/10.1093/acrefore/9780190264093.013.119

\title{
POTENCIJAL ETIKE VRLINA U ETIČKOM OBRAZOVANJU U SLOVAČKOJ
}

\author{
Barbora Bad'urová
}

Etika vrlina pristup je normativne etike koji naglašava izvrsne karakterne osobine moralnih subjekata. Značajan broj autora ističe da ovaj pristup ima veliki potencijal u suvremenom etičkom obrazovanju. Rad se usmjerava na mogućnost uporabe etike vrlina u etičkom obrazovanju u Slovačkoj. Jedan od najznačajnijih autora u razvoju ove teme je Ladislav Lenz koji je napisao i ključne tekstove za nastavnike o etičkom obrazovanju. Njegov se koncept temelji na pedagoškim $i$ psihologijskim osnovama, a inspiriran je konceptom prosocijalnosti španjolskog psihologa R. R. Olivara. Ipak, neki od Lenczovih radova iskazuju i elemente etike vrlina. U ovome radu istaknut ćemo mogućnosti uključivanja etike vrlina u etičko obrazovanje.

Ključne riječi: etičko obrazovanje, etika vrlina, Slovačka 